\title{
MULTI-STAKEHOLDER WORK INTEGRATED LEARNING MODEL FOR HIGHER EDUCATION - A TRANSDISCIPLINARY APPROACH
}

\author{
M. Wait* \\ Marketing Management \\ e-mail: mwait@uj.ac.za
}

\section{M. Govender*}

Industrial Psychology and People Management

e-mail: cookieg@uj.ac.za

*University of Johannesburg

Johannesburg, South Africa

\section{ABSTRACT}

Work integrated learning (WIL) is essential to successful higher education curricula and qualifications. Traditional WIL models are discipline specific with collaboration between educator and business aimed at providing the student with workplace experience. There is a need for a transdisciplinary approach to WIL as well as a need to consider multiple stakeholder responsibility in WIL models.

This conceptual article provides a critical review of two discipline specific WIL models in order to reshape them into a third transdisciplinary multi-stakeholder WIL model highlighting the roles of student, education, business and government. Two working WIL models currently in use in two different disciplines, namely the Human Resources and Marketing Departments, were reviewed for similarities and gaps. The review resulted in the proposed Multi-Stakeholder WIL Model. The message of this article is that for WIL models to be effective and economically viable, government and the students must become key stakeholders.

Key words: work integrated learning, multi-stakeholder WIL model, higher education, transdisciplinary, HRM, Marketing

\section{INTRODUCTION}

Work integrated learning (WIL) has infiltrated the higher education landscape in recent years at an accelerated pace, especially in South Africa (SA). Lecturers are expected to include WIL into their traditional academic curricula for a variety of reasons, including: compliance with national and international imperatives; aligning theory to practice; exposing students to experiential, practical skills; and increasing student opportunity for employability after graduation (CHE 2011). The directive for a WIL curriculum, its implementation and assessment is regulated by national legislation, guidelines and best practice documents; as well as by 
institutional policy and procedures (Engel-Hills, Garraway, Jacobs and Winberg 2012).

South Africa's National Development Plan (South Africa 2011a) highlights the sustainable development of all citizens with business, government and civil society playing inter-related roles in order to improve the lives of all South Africans. The Green Paper for PostSchool Education and Training (South Africa 2012) specifically highlights the responsibility of higher and further education and training institutions to ensure that the education and training they deliver meet the needs of the graduate-to-be, society and the economy.

The Council for Higher Education document titled: Work-Integrated Learning: Good Practice Guide (CHE 2011, 16-21), outlines four main curricular models in SA that align workplace experience (practical) and academic interests (theory) as follows: work-directed theoretical learning (WDTL); problem-based learning (PBL); project-based learning (PjBL); and workplace learning (WPL). The latter, WPL, is commonly referred to as WIL in the South African context (SATN 2008). Other applicable regulations that promote WIL include the National Skills Development Strategy III (South Africa 2011b) and the National Skills Accord (South Africa 2011c).

SA’s Higher Education Quality Council (HEQC 2004, 26) defines WIL as:

... the component of a learning programme that focuses on the application of learning in an authentic learning workplace context under the supervision and/or mentorship of a person/s representing the workplace. It addresses specific competencies identified for the acquisition of a qualification that makes the learner employable and assists in the development of related personal attributes. Workplace/service employees and professional bodies are involved in the assessment of the learning experience, together with university academic employees.

Typical traditional WIL models (Beham, Kump, Ley and Lindstaedt 2010) engage these three key stakeholders: educator, business and student. The educator role constitutes the following: informing and motivating students towards effective WIL implementation; inviting business and business as WIL partners who accept students into their workplaces; and assessing and evaluating student WIL experiences after implementation. The business role entails orientating students into the business; exposing students to business practices; being a potential employer of choice; and proving feedback to the educator on the WIL implementation and improvement opportunities. The student role includes being the learner of theory in the classroom; being the trainee who gains knowledge and skills in the workplace; and becoming a potential future employee of choice (Beham et al. 2010; Cord and Clements 2010; Bates 2008).

The gap arises as this traditional WIL model with the triple stakeholder partnership of education, business and student is incomplete according to national or international imperatives. 
In light of the triple helix partnership perspective (Etzkowitz 2010; Ruuska and Teigland 2009; Etzkowitz and Klofsten 2005) where collaboration between universities, government and business/industry is promoted for socio-economic benefits, the traditional WIL model lacks a key stakeholder, namely government. Chapman (2004) states that the consequences of excluding government from a WIL model are that entrepreneurship at the university may be limited; HEI and business initiatives may be threatened by being indifferent to national imperatives; insecure support structures may be the result; misaligned regional, sector and national growth paths may result; and state funding sources may not be accessible (Smith et al. 2009; Chapman 2004).

This article employs a conceptual framework approach to understand, compare and improve WIL models (Leshem and Trafford 2007). The aim of the article is to critically review two traditional, discipline specific WIL models in order to reshape them into a third transdisciplinary multi-stakeholder WIL model that highlights the roles of student, education, business and government. The intention of the article is to encourage educators to take a multidisciplinary, multi-stakeholder approach to WIL so that students benefit from business and government initiatives and resources.

This section provided an introduction to this article. The next section of this article provides an overview of the literature on traditional WIL models, transdisciplinary approaches to WIL and WIL stakeholders. Thereafter, the two discipline specific WIL models implemented in the Human Resource Management (HRM) and Marketing Management departments are presented. The similarities, differences and gaps in these models are examined and integrated using a transdisciplinary approach. An improved, phased, multi-stakeholder WIL model is presented as an economically viable way forward.

\section{LITERATURE REVIEW}

\section{Traditional WIL models}

Freudenberg, Brimble and Cameron (2011) indicate that various WIL models, frameworks or processes are employed in universities or Higher Educational Institutions (HEIs), depending on the institutional policies, practices and resources. Common to most HEIs are the alignment of WIL to authentic learning, generic skills, career development, skills shortages and employability.

The Workplace Learning Context model (Ulbrich, Scheir, Lindstaedt and Görtz 2006) allows students to retrieve and align organisational knowledge to learning theory during self- 
directed learning experiences. Several learning contexts or spaces provide for task, competency and domain-related support in the work space, learning space and knowledge space. This model is used as a competency performance approach to improve the quality and quantity of workplace task accomplishment (Lindstaedt, Beham, Kump and Ley 2009; Ley et al. 2008; Ulbrich et al. 2006).

The process model (Bates 2008) is used to promote teaching, learning and research, including workplace experiential learning. In this model, workplace-based experiences are built into undergraduate degrees using the key outcomes and challenges that students face with curriculum and workflow procedures. It focuses on knowledge as a commodity, as well as the principles and processes for successful WIL implementation (Bates 2008). The construct measurement model (Smith 2012) considers authenticity; integrated learning support structures at university and the workplace; alignment of teaching, learning, assessment and integrated outcomes; supervisor access; induction or preparation processes; partnerships; and community engagement (Smith 2012; Harris, Jones and Coutts 2010). The Stakeholder Engagement Model (Cord and Clements 2010) proposes a triple partnership agreement with student, faculty/HEI and organisation. While the student gains the learning experience, the faculty provides the disciplinary knowledge and the organisation provides the practical opportunity. The purpose is to enable students to achieve their learning outcomes and the generic attributes of quality, flexibility and sustainability.

All these models have an identifiable gap in that government and economic viability for placing, supporting and integrating students into the workplace are missing. Most significantly noted, however, are the recent strengthened commitment of including WIL into HEI strategic goals, involvement of government as a key stakeholder, and reengineered management and support structures for WIL implementation (Freudenberg et al. 2011; McLennan and Keating 2008; Patrick et al. 2008).

\section{Transdisciplinary approach to WIL}

Most traditional WIL models are discipline specific. For example, practicums, placements and simulations are evident in Education and the Health Sciences; whilst in Business Management, internships and cooperative education are more typical. Instead of models, there are also a variety of WIL phases and structures depending on the discipline. Discipline specific WIL differs or are similar depending on time of implementation: organised as a solid block of time, or a day or a week spread over a certain period, or in a capstone unit at the end of the curriculum. The key difference is whether the aim of the project is to prepare students for paid work after 
the qualification, or to support students who are already working in the field and studying concurrently in the same field (Cord and Clements 2010; Franz 2007; Steiner and Posch 2006).

Cord, Bowdry and Clements (2011) state that internship appointments comprise a recognised approach to WIL that offers undergraduate students the chance to learn their discipline through multidisciplinary practice. Although there is diversity in the ways that internship programmes are established across disciplines, this diversity has led to differences in areas such as structure, assessment, supervision and purpose with similarities in phases, processes and resources.

Interdisciplinary, multidisciplinary, transdisciplinary and cross-disciplinary approaches are recommended for classroom and workplace learning as they increase and enhance the holistic learning experience for students (Dyer 2003). Employing two or three discipline experts collaborating to provide integrated workplace learning to students, allows for a more structured approach to placement, funding and research. Disciplinary curricula, institutional policies, business partnerships, government structures and community resources must be integrated for effective WIL implementation (Thompson Klein 2004).

The conceptual approach of this article supports a transdisciplinary approach to WIL management and leadership to promote effectiveness, efficiency and economic viability of WIL implementation. Furthermore, a transdisciplinary approach enhances the stipulation of and the integration of key stakeholders in WIL models.

\section{Key Stakeholders in WIL models}

Managing WIL is a strategic task that involves four key stakeholders as follows: students, educator, business and government (World Bank Group 2012). Students seek hands-on multiskilling experiences and knowledge in order to cope with and gain successful employment in a globalised, multilingual, multicultural, multigenerational workplace after graduation. Educators, especially HEIs, aim to create future-fit graduates with relevant knowledge, skills, values, attitude and workplace experience. Businesses seek talented, work-ready graduates who have the right skills set for the right job and are potential future employees of choice. Governments seek to grow the economy, offset the misaligned skills supply-demand statistics, mitigate the scarce and critical skills shortages and solve the challenges of unemployment, poverty and inequality (World Bank Group 2012; Orrell 2004).

All stakeholders have strategic roles to play in effective WIL implementation if multiple benefits are to accrue to each (Cooper, Orrell and Bowden 2010). Students benefit from WIL by gaining practical experience in the theory learned in class, increasing their employability 
skills, and the opportunity to select their employer of choice. Lecturers or HEIs benefits include compliance to national imperatives, forming partnerships with business and government, aligning curriculum by linking theory to practice and enhancing their image to promote socioeconomic imperatives. Businesses or employers benefit from the opportunity to observe and select future new recruits from the potential graduate-to-be talent available, meet national skills development imperatives, gain student-workers at no or low cost, as well as gain authentic feedback on their policies, procedures and practices. Government benefits include achieving national skills development targets, spending public funds on promoting employability, and ensuring a qualified workforce with relevant critical and scarce skills (Smith et al. 2009; Patrick et al. 2008; Abeysekera 2006).

\section{HRM AND MARKETING DISCIPLINE SPECIFIC WIL MODELS}

The University of Johannesburg (UJ) is a South African comprehensive HEI that offers both vocational and professional programmes. The University's Faculty of Management aims to create future-fit leaders by aligning itself to the University's learning-to-be teaching, learning and assessment philosophy and strategy. Within this Faculty, the Department of Industrial Psychology and People Management (HRM) and the Department of Marketing Management offer a range of qualifications from diploma to doctorates in their respective disciplines. Both these departments aim to equip their students with the requisite theoretical, practical and reflexive knowledge, skills, values and attitudes in readiness for entering the workplace as future-fit graduates when exiting their qualification.

During 2012-2014, both departments piloted and promoted two separate but similar WIL models with similar phases, processes and resources. The HRM programme implemented the WIL Partnership Model for the students in the HRM Diploma. The Market Management programme implemented the DSA-UJ Project Model for students in the Marketing Diploma. A transdisciplinary approach was adopted to compare, integrate and reshape these two discipline specific WIL models towards a third, multi-stakeholder WIL model.

\section{HRM WIL Partnership Model}

The HRM WIL Partnership Model, presented in Table 1, is a framework consisting of five phases implemented over a period of 10-12 months as follows: design, develop and approval; preparation; implementation; evaluation; and review phases. Each phase has 4-5 processes requiring essential resources. 
Table 1: HRM WIL Partnership Model

\begin{tabular}{|c|c|}
\hline \multicolumn{2}{|c|}{ Phase 1: Design, develop and approve WIL model (2 months) } \\
\hline Processes & Resources \\
\hline $\begin{array}{l}\text { 1. Conceptualise WIL model and } \\
\text { develop the model outline }\end{array}$ & Conceptualisation and agreement in WIL Project Team \\
\hline $\begin{array}{l}\text { 2. Identify pilot student group/s and } \\
\text { business partners }\end{array}$ & $\begin{array}{l}\text { Final year HRM Diploma students + existing and new business } \\
\text { partners }\end{array}$ \\
\hline $\begin{array}{l}\text { 3. Consult with stakeholders for } \\
\text { approval, support and review }\end{array}$ & $\begin{array}{l}\text { Faculty of Management Experiential Learning Committee; HRM } \\
\text { Department leadership team; HRM programme team; qualification } \\
\text { leader; class lecturer; students; business partners; UJ PsyCAD } \\
\text { Services for work readiness preparation }\end{array}$ \\
\hline 4. Develop the support documentation & $\begin{array}{l}\text { Learning Guide, letters of introduction to the company, pro forma } \\
\text { Memorandums of Understanding, PowerPoint presentations, WIL } \\
\text { information packs and brochures }\end{array}$ \\
\hline $\begin{array}{l}\text { 5. Communicate the compulsory, non- } \\
\text { remuneration WIL project plan }\end{array}$ & $\begin{array}{l}\text { Learning Guide: } 40 \text { hours of WIL component; link to specific } \\
\text { outcomes (SOs) and assessment criteria (ACs); Portfolio of } \\
\text { Evidence (POE) criteria and assessment; allocation of marks }\end{array}$ \\
\hline \multicolumn{2}{|c|}{ Phase 2: Preparation for implementation of WIL model (2 months) } \\
\hline Processes & Resources \\
\hline $\begin{array}{l}\text { 1. Awareness and information sessions: } \\
\text { preparation of stakeholders for WIL } \\
\text { programme }\end{array}$ & Students; lecturer; project team; PsyCAD; business partners \\
\hline 2. Distribute WIL information packs & $\begin{array}{l}\text { Students and business: memos; letters; brochures; POE criteria; } \\
\text { forms; declaration }\end{array}$ \\
\hline $\begin{array}{l}\text { 3. Prepare students for entry into } \\
\text { workplace }\end{array}$ & $\begin{array}{l}\text { Workplace readiness workshops: job search; CV writing; interview } \\
\text { skills; dress code; business etiquette; tax numbers; bank accounts }\end{array}$ \\
\hline 4. Finalise business partner base & $\begin{array}{l}\text { Student employer of choice, HRM Programme Advisory Board } \\
\text { members and other business partners }\end{array}$ \\
\hline \multicolumn{2}{|r|}{ Phase 3: Implement WIL model (3 months) } \\
\hline Processes & Resources \\
\hline 1. Confirmation of placement list & $\begin{array}{l}\text { Signed letters from business partners (supervisor/ mentor) per } \\
\text { student; establish database of partners }\end{array}$ \\
\hline 2. Risk management & Indemnity forms; business and UJ WIL Insurance provisions \\
\hline $\begin{array}{l}\text { 3. Support base for students and } \\
\text { partners communicated }\end{array}$ & $\begin{array}{l}\text { UJ support services (PsyCAD), WIL Project Team, lecturer and } \\
\text { business, supervisor/ mentor }\end{array}$ \\
\hline $\begin{array}{l}\text { 4. Tracking and feedback from students } \\
\text { and supervisors }\end{array}$ & $\begin{array}{l}\text { As per structured POE: progress reports; attendance and } \\
\text { performance tasks; challenges experienced; competencies } \\
\text { displayed; employability growth reflection journal }\end{array}$ \\
\hline \multicolumn{2}{|c|}{ Phase 4: Evaluate WIL model (2 months) } \\
\hline Processes & Resources \\
\hline 1. Feedback from POE assessment & Students and lecturer; SOs and ACs \\
\hline 2. Feedback from students & WIL Project Team: quantitative and qualitative research \\
\hline 3. Feedback from business partners & WIL Project Team: quantitative and qualitative research \\
\hline $\begin{array}{l}\text { 4. Evaluation, recognition and } \\
\text { appreciation. }\end{array}$ & Award ceremonies for business partners and other stakeholders \\
\hline \multicolumn{2}{|c|}{ Phase 5: Review WIL model (1 month) } \\
\hline Processes & Resources \\
\hline 1. What worked? & WIL Project Team: SWOT report \\
\hline 2. What did not work? & Stakeholders to manage project risks \\
\hline 3. What should change? & Stakeholder consultation and agreement \\
\hline 4. Revise and improve model & WIL Project Team, lecturer and students \\
\hline
\end{tabular}

Phase 1: Design, development and approval of the WIL model, which involves five processes: adopt or design the WIL model; identify students and business partners; consult with stakeholders for approval, support and review; develop the supporting documentation and communicate the details of the WIL project plan. Essential resources required for Phase 1 include: WIL project team; students and business partners; faculty committees, departmental 
teams and lecturer; communication via learning guides with specific outcomes (SOs), assessment criteria (ACs), timelines and weighting of marks; letters and presentations to business; and memorandums of understanding.

Phase 2: Preparation to implement the WIL model, which involves four processes: awareness and information sessions to prepare stakeholders; distributing WIL information packs; preparing students for entry into the workplace; and finalising the business partners. Essential resources required for Phase 2 are: students; lecturer; WIL project team; academic support services; business partners; information packs, portfolio of evidence (POE) criteria and relevant forms; workplace readiness workshops to empower students on job search, CV writing, interview skills, dress code, and business and financial etiquette.

Phase 3 is the implementation phase requiring these processes: confirmation of placement list; indemnity and risk management; support base for students and partners communicated; tracking and feedback from students and supervisors. Resources required for Phase 3 are: signed letters from supervisors; database of business partners; indemnity and safety assurance; and POE with progress reports.

Phase 4 evaluates the WIL model via these processes: feedback; and evaluation, recognition and appreciation of stakeholders. Resources required are lecturer assessment ratings of student POEs; student and business quantitative and qualitative feedback; and acknowledgement of participating stakeholders.

Phase 5, the review phase, concludes the model with processes focussing on questions and solutions for improving the model design. The essential resources for this phase are the analysis of the strengths, weakness, opportunities and threats of the WIL partnership model; risk management; stakeholders; and improvement suggestions.

\section{Marketing Management WIL Model}

The Marketing Management WIL Model, presented in Figure 1, represents four phases implemented over a period of 10 months as follows: the preparation; agreement; operation; and control phases. Each phase involves essential processes that require specific resources.

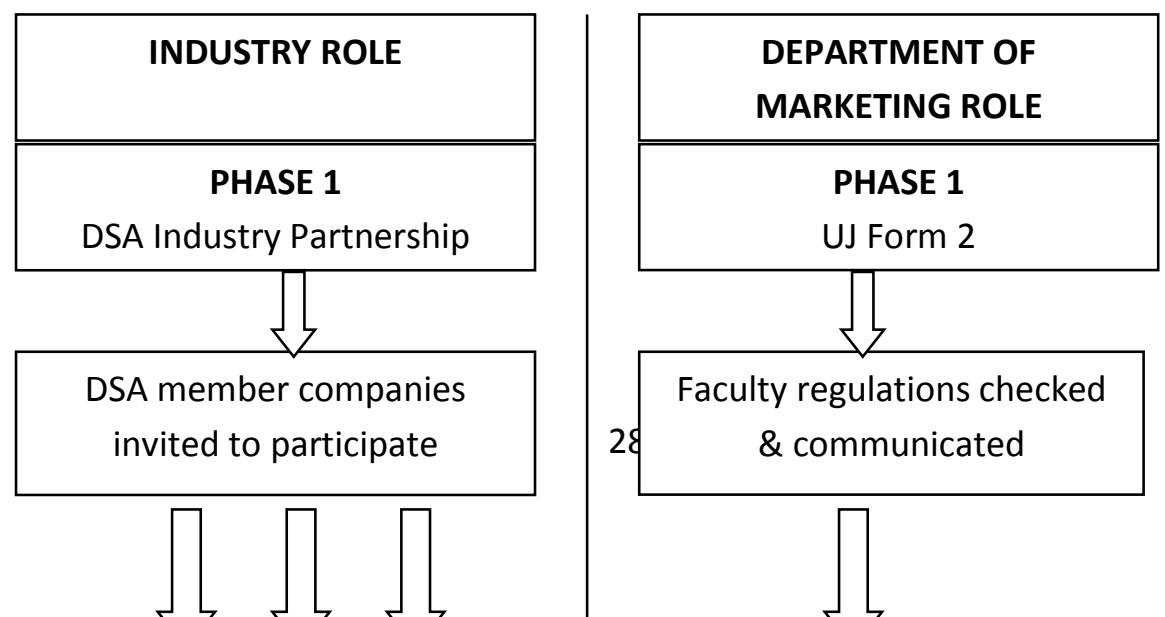


Figure 1: Marketing Management WIL Partnership Model

Phase 1: Preparation, requires two management streams: business (DSA) and educator (UJ). The DSA invites and manages participating member companies. Companies are informed of expectations, roles and responsibilities. Individual companies sign an agreement of understanding with the DSA Chairperson.

Phase 2: Agreement, comprises when UJ complies with institutional regulations. The Programme Manager and Head of the Marketing Department are responsible. Both parties (DSA and UJ) sign the DSA-UJ Project agreement with respective roles and responsibilities. Classroom allocation, project leaders, business accessibility to students, accurate interactive database, product training, and delivery schedules are clarified. Student participation is also covered in the agreement for clarity on attendance, payment schedules, sales targets and the monitoring of their progress.

Phase 3: Operations, which begins with participating companies marketing their products to students. Students interact with companies, ask questions, scrutinise product ranges, and make decisions on which company to work with. Direct marketing and sales by students are 
recorded and assessed by DSA.

Phase 4: Control: DSA uploads, monitors and manages participating companies and students throughout the year using its online database. The DSA-UJ Project runs live on the DSA website as a read-only, password protected database. Student profiles, sales progress, targets and assessments can be viewed and tracked. On-campus IT facilities allow students and lecturers to check their sales progress and assessments.

\section{Similarities and gaps in discipline specific HRM and Marketing WIL models}

Although the discipline specific HRM and Marketing WIL models may look different when compared to each other, they have more similarities than differences. The similarities noted in these two WIL models include: a phased approach; processes and resources within phases; Diploma students; invitation to and agreements with business partners; an HEI project team; student self-placement in organisation; risk management; tracking; assessment; feedback; and review of the model. A further similarity was acknowledging the fact that the student as a key stakeholder was largely ignored by most WIL models in the literature, especially in the triple helix partnership approach. Instead the student is viewed as the recipient or end product or an output of the socio-economic partnership process.

After pilot implementation, the gaps identified by both models are also similar as follows: they need to include government as a key stakeholder in the model; recognition of the triple helix partners (education, business and government); budgeting for effective WIL implementation; funding for students during WIL placement; and accessing Sector Education and Training Authority (SETA) grants.

The next section of this article presents an integration and improvement of the discipline specific HRM and Marketing WIL models using a transdisciplinary approach. This means incorporating all similarities of the discipline specific models, taking into consideration all identified gaps, and furthermore acknowledging that there should be at the minimum, four key stakeholders in any successful WIL model: student, educator, business and government.

\section{TRANSDISCIPLINARY MULTI-STAKEHOLDER WIL MODEL}

Formal and informal presentations and communication at faculty meetings resulted in joint collaboration amongst the two discipline specific WIL model project team leaders. Both leaders acknowledged the similarities amongst the models, as well as recognised the need to improve and hence revise their WIL models. Simultaneously, both leaders identified and agreed on 
similar gaps in each model. Discussions led to decisions on improving, revising and presenting a transdisciplinary WIL model for implementation in the faculty and institution.

The discipline specific HRM and Marketing WIL models were integrated, simplified and reshaped to include the triple helix stakeholders, as well as highlight the student and government as key stakeholders. The revised model was named the Multi Stakeholder WIL Model as presented in Figure 2.

The Multi Stakeholder WIL Framework comprises of four stakeholders, each with specific roles in four phases. The four stakeholders include the student, education, business and government. The four phases are as follows: Phase 1: prepare, present and gain approval for the WIL project plan; Phase 2: secure all stakeholder agreements; Phase 3: students gain WIL experience in the workplace; and Phase 4: all stakeholders are contacted for feedback on how they experienced the WIL implementation.

During Phase 1, the preparation phase, the processes include identifying, engaging and motivating the students to seek self-placements for their experience WIL as part of their module curriculum; inviting the relevant businesses and SETAs to partner as key stakeholders in implementing the WIL model; developing the relevant documents such as information packs and memorandums of understanding; and ensuring that stakeholder communication and awareness are effective.

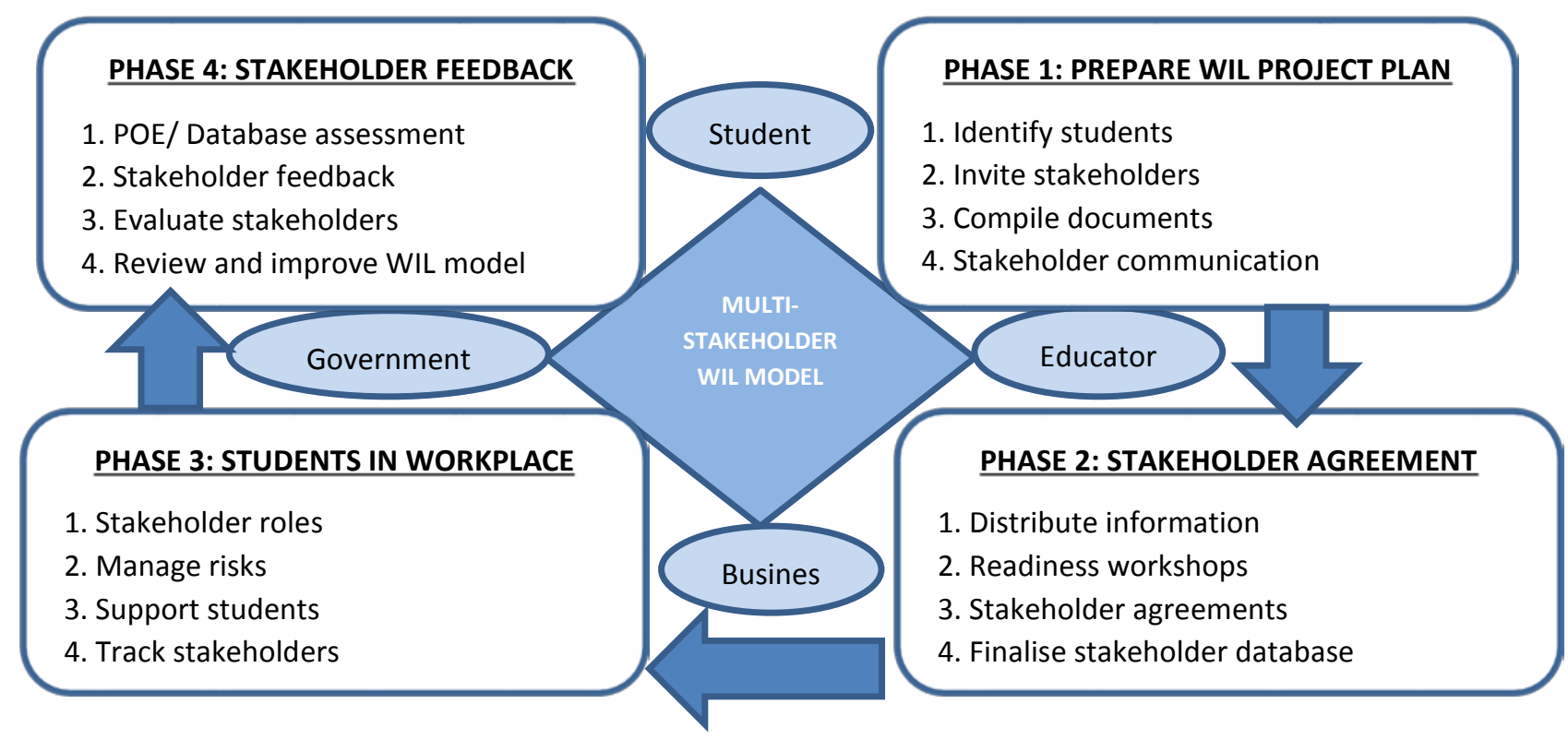

Figure 2: Multi-Stakeholder WIL Model

In Phase 2, the stakeholder agreement phase, the processes involve distributing the relevant contractual information to all stakeholders; ensuring that students are committed to and attend work-readiness workshops such as CV writing, job search, interview skills, and business etiquette; signing or securing the relevant stakeholder agreements, especially the student- 
employer and student-SETA agreements; and finalising stakeholder participation and setting up the required database for capturing of relevant information electronically.

The processes of Phase 3 when students are in a workplace consist of clarifying and ensuring that stakeholder roles are executed efficiently and effectively; that all risks that threaten the success of the WIL implementation are identified and managed speedily; that effective support structures are established for students if they experience challenges with WIL implementation; and that a tracking system is established to record all stakeholder activities.

During Phase 4, the stakeholder feedback phase, the processes entail the students compiling and handing in of POEs or updating the required database so that they may be assessed for their WIL; educators gathering stakeholder feedback by conducting quantative and qualitative research; educators evaluating stakeholder participation and commitment to the WIL model; and finally, reviewing and improving the WIL model in readiness for implementation in the next academic year.

The Multi-Stakeholder WIL Model integrates two discipline specific models and presents a transdisciplinary approach to WIL management and leadership. Furthermore, this model addresses the gap found in that it acknowledges that compared to traditional WIL models where only educators and business are viewed as significant stakeholders, students and government must also become key stakeholders if WIL implementation is to be successful.

\section{CONCLUSION}

WIL has become a very important factor to consider when developing academic curricula. Several government initiatives, namely the South Africa's National Development Plan, the Green Paper for Post School Education, the Work Integrated Learning - Good Practice Guide, and the triple helix partnership imperative, exert pressure on education, business and government to promote effective WIL management and leadership. Traditional, discipline specific WIL models have been found to be lacking in including all four key stakeholders, namely students, education, business and government, and in clearly identifying their roles and involvement opportunity. Furthermore, discipline specific models within facilities are unnecessary and are tantamount to a silo-based approach.

This article aimed to highlight the use of a transdisciplinary approach to integrate two traditional WIL models and bridge the gap in both discipline specific models whereby the role of the student and government as key stakeholders is lacking. A critical review of the two discipline specific WIL models resulted in a third reshaped WIL model, the phased, MultiStakeholder WIL Model. Government involvement in WIL models is imperative to address 
legislative compliance, provide avenues for funding and mitigating graduate unemployment.

This article contributed to a better understanding of how traditional, discipline specific WIL models can be reshaped to improve effectiveness, efficiency and successful WIL implementation. A recommendation of this article is that the proposed transdisciplinary MultiStakeholder WIL model be tested with empirical research in order for this WIL model to be validated.

For WIL implementation, management and leadership to be taken seriously, students as a key stakeholder in the WIL model have to be supported by educators, business and government. Although theoretical and practical knowledge and skills may motivate students who are graduates-to-be, stipends for travel, refreshment and subsidiaries from government skills levies and grants may be a direct incentive for students to strive to enter the workplace.

\section{REFERENCES}

Abeysekera, I. 2006. Issues relating to designing a Work-Integrated Learning (WIL) program in an undergraduate accounting degree program and its implications for the curriculum. Faculty of Commerce-Papers: 539.

Bates, M. 2008. Work-integrated curricula in university programs. Higher Education Research and Development 27(4): 305-317.

Beham, G., B. Kump, T. Ley and S. Lindstaedt. 2010. Recommending knowledgeable people in a workintegrated learning system. Procedia Computer Science 1(2): 2783-2792.

Chapman, J. 2004. System failure: Why governments must learn to think differently. Demos.

Cooper, L., J. Orrell and M. Bowden. 2010. Work integrated learning: A guide to effective practice.

Cord, B., G. Bowdrey and M. Clements. 2011. A regional WIL model: Sharing a new approach. AsiaPacific Journal of Cooperative Education 12(3): 163-174.

Cord, B. and M. Clements. 2010. Managing the transition from the classroom to the workplace: Beyond the duty of care. Ascilite 2010 Conference, 226-230. Sydney: Ascilite.

CHE, see Council for Higher Education.

Council for Higher Education. 2011. Work-Integrated Learning: Good Practice Guide. Pretoria: IeCommunications.

Dyer, J. A. 2003. Multidisciplinary, interdisciplinary, and transdisciplinary educational models and nursing education. Nursing Education Perspectives 24(4): 186-188.

Engel-Hills, P., J. Garraway, C. Jacobs and C. Winberg. 2012. Work-integrated learning: A good practice guide. Workshop on work-integrated learning for public institutions: 24 February 2012. Murisi Auditorium, CHE, Pretoria.

Etzkowitz, H. 2010. The triple helix: University-business-government innovation in action. Routledge.

Etzkowitz, H. and M. Klofsten. 2005. The innovating region: Toward a theory of knowledge-based regional development. $R \& D$ Management 35: 243-255. doi: 10.1111/j.1467-9310.2005.00387.x.

Franz, J. M. 2007. Work integrated learning for design: A scholarship of integration.

Freudenberg, B., M. Brimble and C. Cameron. 2011. WIL and generic skill development: The development of business students' generic skills through work-integrated learning. Asia-Pacific Journal of Cooperative Education 12(2): 79-93.

Harris, L., M. Jones and S. Coutts. 2010. Partnerships and learning communities in work-integrated 
learning: Designing a community services student placement program. Higher Education Research and Development 29(5): 547-559.

HEQC, see Higher Education Quality Council.

Higher Education Quality Council. 2004. Criteria for Institutional Audits. Pretoria: Council for Higher Education.

Leshem, S. and V. Trafford. 2007. Overlooking the conceptual framework. Innovations in Education and Teaching International 44(1): 93-105.

Ley, T., A. Ulbrich, P. Scheir, S. N. Lindstaedt, B. Kump and D. Albert. 2008. Modeling competencies for supporting work-integrated learning in knowledge work. Journal of Knowledge Management 12(6): 31-47.

Lindstaedt, S. N., G. Beham, B. Kump and T. Ley. 2009. Getting to know your user - Unobtrusive user model maintenance within work-integrated learning environments. In Learning in the Synergy of Multiple Disciplines, 73-87. Springer Berlin Heidelberg.

McLennan, B. and S. Keating. 2008, June. Work-integrated learning (WIL) in Australian universities: The challenges of mainstreaming WIL. In ALTC NAGCAS National Symposium.

Orrell, J. 2004. Work-integrated learning programmes: Management and educational quality. In Proceedings of the Australian Universities Quality Forum 2004, 1-5. AUQA Occasional Publication.

Patrick, C. J., D. Peach, C. Pocknee, F. Webb, M. Fletcher and G. Pretto. 2008. The WIL (Work Integrated Learning) report: A national scoping study [Final Report]. Queensland University of Technology.

Ruuska, I. and R. Teigland. 2009. Ensuring project success through collective competence and creative conflict in public-private partnerships - A case study of Bygga Villa, a Swedish triple helix egovernment initiative. International Journal of Project Management 27(4): 323-334.

SATN. 2008. Position paper on work-integrated learning (WIL) in the new HEQF. South African Technology Network.

South Africa. 2011a. National Development Plan: Vision for 2030. Pretoria: Government Printer.

South Africa. 2011b. National Skills Accord. Pretoria: Government Printer.

South Africa. 2011c. National Skills Development Strategy III (2011-2016). Pretoria: Government Printer.

South Africa. 2012. Green Paper for Post-School Education and Training. Pretoria: Government Printer.

Smith, M., S. Brooks, A. Lichtenberg, P. McIlveen, P. Torjul and J. Tyler. 2009. Career development learning: Maximising the contribution of work-integrated learning to the student experience: Australian Learning and Teaching Council Final Project Report. University of Wollongong, Careers Central, Academic Services Division.

Smith, C. 2012. Evaluating the quality of work-integrated learning curricula: A comprehensive framework. Higher Education Research and Development 31(2): 247-262.

Steiner, G. and A. Posch. 2006. Higher education for sustainability by means of transdisciplinary case studies: An innovative approach for solving complex, real-world problems. Journal of Cleaner Production 14(9): 877-890.

Thompson Klein, J. 2004. Prospects for transdisciplinarity. Futures 36(4): 515-526.

Ulbrich, A., P. Scheir, S. N. Lindstaedt and M. Görtz. 2006. A context-model for supporting workintegrated learning. In Innovative approaches for learning and knowledge sharing, 525-530. Springer Berlin Heidelberg.

World Bank Group (Ed.). 2012. World Development Indicators 2012. World Bank Publications. 